\title{
Sūrat al-Fajr (Q. 89): A Study of Structure, Meaning and the Value of Analysis
}

\author{
M.A.S. Abdel Haleem \\ SOAS, UNIVERSITY OF LONDON
}

In his one-paragraph introduction to his translation of this early Meccan sura (30 short verses), Richard Bell describes it as follows: 'The introductory oath is not very intelligible or well arranged and does not lead up to any important statement. The rest of the sura is confused in rhyme and the sense is also uneven ... A number of verses were introduced into the sura at a later date which cannot be determined' and continues, 'How the various parts of the sura came to be conjoined it is impossible to say. ${ }^{1}$ His work is littered with such indications of uncertainty as 'seems, probably possibly, looks like, not intelligible, impossible to say, cannot be determined'. In the following discussion we will test the validity and value of Bell's observations.

Bell was one of the most prominent translators and scholars on the Qur'an writing in English in the twentieth century. In both his translation (1937, reprint 1960) and in his two-volume Commentary on the Qur'an (published posthumously in 1991), Bell was significant for being the first English translator to discuss the structure of the entire Qur'an, from beginning to end. ${ }^{2}$ Although the study of the Qur'an in the West has progressed since the publication of Bell's work on the Qur'an, he has been frequently quoted and discussed by subsequent scholars, including Angelika Neuwirth, Neal Robinson, Alan Jones, and myself. In this discussion of Sürat al-Fajr Bell's views must still be taken seriously, hence my critical discussion here, which takes the form of a close reading of the sura in four sections: vv. $1-5,6-14,15-26$, and $27-30 .^{3}$

\section{Background}

As will be seen below, careful reading of this sura indicates that it was revealed at a time when the Prophet felt particularly downhearted at the oppression exercised by some Meccan leaders particularly over orphans and the poor. Sürat al-Fajr brings consolation, showing that the oppression and oppressor will not last indefinitely and God is on the watch and will punish the oppressors. Concern for 
orphans and the poor is a recurring theme in the Qur'an (see for example Q. 93 and 107 (Meccan), and Q. 4:1-6 and 8-10 (Medinan). Frequently mention of orphans and the poor follows immediately after instructions to worship God and be good to parents (for example Q.17:26 and 34, Q. 6:152, and Q. 4:36). The Prophet, having himself been left an orphan, seems particularly moved and grieved by the oppression of orphans. The passage about orphans in the third section of Sürat alFajr is an example.

\section{Section 1: Verse 1-5}

To make its point strongly, the sura begins with the following oath (oaths in the Qur'an give more emphasis than mere particles and words of emphasis): ${ }^{1} B y$ the dawn, ${ }^{2}$ by ten nights, ${ }^{3}$ by the even and the odd, ${ }^{4}$ by the night as it passes. The use of the oath wa'l-fajr (By the dawn) in verse 1 is a powerful and fitting start to the sura, as fajr derives from the root $f-j-r$, 'to gush forth, explode', ${ }^{4}$ an apt description of the spreading of the sun's light over the earth as it dispels the long darkness of night and starts a new day. The exact significance of the oath By ten nights is less obvious, ${ }^{5}$ and al-Rāzì sums up the opinions of various exegetes that the ten nights refer to the last ten nights of Ramaḍān, including the Night of Glory/Destiny (laylat $a l$-qadr), or to the first ten nights of Dhü'l-Hijjah, including the rituals of Hajj, or to the first ten nights of Muharram, culminating in the day of 'ashūra. ${ }^{6}$ The various Muslim commentators' explanations cited by al-Rāzī clearly stem from religious feelings about the importance of the months of Ramaḍan, Dhu'l-Hijjah, and Muharram and their religious rituals. It is understandable that the faithful should seek support in Qur'anic references for significant times and events, but there are serious obstacles to attribution of the ten nights referred to in Sürat al-Fajr to these months: it is anachronistic. Al-Fajr is an early Meccan sura and all these ritual dates, important surely as they came to be, gained their importance much later, in Medina. Besides, the Hajj takes place in five days, not ten, from the ninth to thirteenth of Dhū'l-Hijjah, and the entire month of Dhū'l-Hijjah, not just ten nights, is regarded as a holy month (shahr harām), as is the whole of the month of Muharram. The importance attached to the early days of Muharram and the day of 'ashüra are perfectly understandable in terms of devotion, but linguistic and historical facts are a different matter. Al-Fajr, as pointed out above, is a very early Meccan Sura preceding all the other occasions referred to above.

This view is further supported by the fact that in Qur'anic oaths in other suras, such as Q. 91, Q. 92, and Q. 931, and also Q. 84:16-18, 'day', 'night', and so on, refer to astronomical phenomena unrelated to any acts of worship. If we accept that the same applies to Sürat al-Fajr, an explanation of the significance of 'ten nights' must be sought elsewhere. I argue that the words in the oath should be understood in their basic, obvious meaning: the time of dawn and ten nights, including even and odd, and the night as it passes. This passing (v. 4) is the key to the meaning of the 
oath. The night here does not stand still (sajā) as in Q. 93:2, or cover (yaghshā) as in sura 92, but passes (yasri), leading to dawn, and this intimates that the oppression of tyrants, mentioned later in the sura, will also pass. Thus, in al-Fajr the Prophet is reassured that the darkness of the night passes, leading to the dawn. (One is reminded here of Imrū al-Qays in his mu 'allaqa bemoaning the length of the night: a-lā ayyuhā al-laylu al-țawīlu alā-njalī bi-șubhin! ('O long night, depart and let the morning in!')). The dawn brings an end to the night-any night: even if there are ten nights, they all end with dawn. 'Ten' is used elsewhere in the Qur'an to show multiplicity and completeness. For example, whoever does a good deed will have ten rewards for it in Q. 6:160), see also 'ashara kāmila 2:196 and Moses' 30 nights, completed with another ten (Q.7:142). So here, the succession of ten confirms that the coming dawn is not simply one accident or event, but a continuous, unaltered pattern.

Many explanations have also been given for the even and the odd (al-shaf'i wa'lwatri) referred to in the following oath (v. 3). For instance, al-Rāzī again sums up various views given by exegetes, saying for instance that this phrase refers to the final sunna prayers at night (called shaf' and watr), composed of two raka 'àt (shaf') followed by another one (watr), or God being one and others being in pairs. ${ }^{7}$ In my view, this oath, coming as it does after wa-layālin 'ashr (By the ten nights), refers to odd and even numbers, which themselves follow each other in succession, just as night yasri (passes) and day follow, ten nights pass, and odd and even also pass, none of them lasting forever. God alternates (yuqallibu) night and day (Q. 24:44), so the Prophet should be aware that God can change things over time. He is told on another occasion, There is no need for you to be impatient concerning them: We are counting down their allotted time (Q. 19:84), especially as Your Lord is on the watch (bi'l-mirșād) (Q. 89:14).

The problem with Qur'anic exegesis of such oaths is that many commentators have tended to be atomistic in their approaches, looking at words and phrases in isolation from their surroundings, without paying regard to the context or exploring what the oath is really driving at, and this often results in the most unlikely interpretations. Many Muslim commentators have also felt they should include all previous interpretations in their discussions, lest they fall into the trap of kitmān al'ilm ('concealing knowledge'). This approach has led some Western scholars to suggest that nobody, including Muslims, knows definitively what Qur'anic statements such as these oaths mean. ${ }^{8}$ Rather than adopting the atomistic approach, I am firmly of the view that a more comprehensive and contextual approach is needed, which takes as its premise the idea that all the elements of the oath work together coherently as an argument to make a point. ${ }^{9}$ If the main objective of the oath in Q. 89:1-4 is to bring relief and encouragement to the Prophet (and it can be assumed that the Prophet is the addressee here, rather than 
the wider community, from the use of the second person singular rabbika (your Lord) in different parts of this sura), then all parts of the oath must also be understood in the same vein; this gives rise to a reading of the oath as referring to the passing night that leads to the dawn, and the passing of the ten nights, even and odd, which should be understood in the same vein, the ultimate message being to encourage the Prophet and show that God is counting down the days for the oppressors.

After the initial, mighty oath reminding the Prophet of God's grace in creating dawn, night, even and odd numbers, and showing the inevitable, astronomical, pattern of night passing, the Prophet is asked in verse 5 , Is this oath strong enough for a rational person? (hal fi dhālika qasamun lidhī hijr). This rhetorical question actually suggests that he had been so worried that he needed to be shaken out of his mindset by God's reassurance.

In Bell's discussion of this sura, he gives his opinion that the oath 'does not lead up to any important statements'. However, in Arabic rhetoric (balāgha) what we have here is a case of hadhf ('omission') of al-muqsam 'alayhi ('what [an oath] is sworn about') because it is understood from the situation. The night passes and your Lord, who ordains this, is watching over what saddens you, Muhammad, and will bring it to an end and punish the oppressors as stated in the following verses. Stating everything that can be understood from the context is contrary to the requirements of balāgha and conciseness in the Qur'an, especially as there is a qarina ('indication', here your Lord is on the watch, at v. 14) to help understanding. ${ }^{10}$

\section{Section 2: Verses 6-14}

${ }^{6}$ Have you [Prophet] not considered how your Lord dealt with [the people] of 'Ad, ' of Iram, [the city] of lofty pillars, ${ }^{8}$ whose like has never been made in any land, ${ }^{9}$ and the Thamud, who hewed into the rocks in the valley, ${ }^{10}$ and Pharaoh with his columns / pyramids? ${ }^{11}$ All of them committed excesses in their lands, ${ }^{12}$ and spread corruption there: ${ }^{13}$ your Lord let a scourge of punishment loose on them. ${ }^{14}$ Your Lord is always on the watch.

Having drawn on the cyclical conception of passing time during its initial oath section, the sura moves on to give evidence from history in verse 6: Have you [Prophet] not considered ...? The rhetorical question is intended to make the Prophet himself agree to the proposition, giving examples of mighty peoples, 'A $\mathrm{d}$ with their columns, Thamūd with their pillars carved into the rock, and Pharaoh with his awtād. ${ }^{11}$ All of these people exercised oppression in their lands and spread corruption (țaghaw fi'l-bilād fa-aktharū fïhā al-fasād, vv. 11-12), so God unleashed on them a whip of punishment. The following phrase, Your Lord [Prophet,] is on the watch (v. 14) assures the Prophet that God is on the watch for oppressors, both in 
history and among his contemporaries in Mecca, ${ }^{12}$ that are mentioned in Section 3, thereby connecting this section to the next section of the sura.

\section{Section 3: Verses 15-26}

${ }^{15}$ [There is the type of] man who, when his Lord tries him through honour and blessings, says, 'My Lord has honoured me,' ${ }^{16}$ but when He tries him through the restriction of his provision, he says, 'My Lord has humiliated me.' ${ }^{17}$ No indeed! You [people] do not honour orphans, ${ }^{18}$ you do not urge one another to feed the poor, ${ }^{19}$ you consume inheritance greedily, ${ }^{20}$ and you love wealth with a passion. ${ }^{21}$ No indeed! When the earth is pounded to dust, pounded and pounded, ${ }^{22}$ when your Lord comes with the angels, row after row, ${ }^{23}$ when Hell is that Day brought near-on that Day man will take heed, but what good will that be to him then? ${ }^{24} \mathrm{He}$ will say, 'Would that I had provided for this life to come!' ${ }^{25}$ On that Day, no one will punish as He punishes, ${ }^{26}$ and no one will bind as He binds.

As we have seen, the second section of the sura address how the people of 'A $d$, Thamūd, and Pharaoh oppressed people in the land. In section three these people are implicitly compared to certain individuals in Mecca who also oppress the weak in a number of ways: they do not help orphans and do not urge each other to feed the poor. They greedily consume inheritances which should rightfully belong to orphans, and, in addition, take whatever else they can from them. ${ }^{13}$ This not only parallels the oppression of the historical figures mentioned in the previous section, but, in fact, is even more depraved, because this wrongdoing is targeted specifically at orphans and the poor. Not only this, but these Meccan oppressors are pleased with God when they have wealth, but displeased with Him when their wealth diminishes. ${ }^{14}$ The Prophet is then told that God, who is watching everything, will bring punishment on these oppressors, even if it does not befall them until the Day of Judgement, just as He instructs Muhammad in Q. 70:5-7 to, be patient, [Prophet], as befits you. ${ }^{6}$ The disbelievers think it [the Day of Judgement] is distant, ${ }^{7}$ but We know it to be close. Whatever faith such an oppressor has is not firm; he is a waverer, as expressed in_Q.70:19-22, ${ }^{19}$ Man was truly created anxious: ${ }^{20}$ he is fretful when misfortune touches him, ${ }^{21}$ but tight-fisted when good fortune comes his way. ${ }^{22}$ Not so those who pray. These unsettled waverers do not help orphans and the poor, even when God has given them wealth, which they themselves admit, instead they seek to increase their own wealth by usurping the inheritance and wealth of the orphans. ${ }^{15}$ So, when wealthy and even when not wealthy they oppress (taghaw) orphans and the poor just as 'Ād, Thamūd, and Pharaoh oppressed people in the past. The oppressors of Mecca, in addition to being displeased with God, have been consumed with love of wealth (... aklan lamman ... hubban jamman, vv.19-20). 
There then follows a description of the punishment that awaits these oppressors for the wrongs they do:

${ }^{21}$ No indeed! When the earth is pounded to dust, pounded and pounded, ${ }^{22}$ when your Lord comes with the angels, row after row, ${ }^{23}$ when Hell is that Day brought near-on that Day man will take heed, but what good will that be to him then? ${ }^{24} \mathrm{He}$ will say, 'Would that I had provided for this life to come!' ${ }^{25}$ On that Day, no one will punish as He punishes, ${ }^{26}$ and no one will bind as He binds.

This impressive scene, of the Day of Judgement, depicted with God's arrival, accompanied by the angels in ranks, when Hell will be brought near, shows the opressors what awaits them. Compare this picture with that given in Q. 26:90-91, ${ }^{90}$ When the Garden is brought near to the righteous ${ }^{91}$ and the Fire is placed in full view of the misguided, and Q. 79:36, When Hell is exposed for all to see. Their anguish is shown when, only then, each of them cries 'If only ...'. On that Day none will punish as God punishes and none will bind as He binds (vv. 25-26). This calls to mind of the incomparable city of Iram with its lofty pillars described in verse 8 , the like of which has never been seen in all the lands, which was also destroyed by God. The fact that this scene does not actually describe the oppressors actually being punished, but does so by hadhf ('omission') makes it all the more awesome; the punishment that awaits them is unimaginable and unspeakable.

\section{Section 4: Verses 27-30}

The contrast with the previous section, in which the guilty were condemned but not directly addressed by God, is striking. ${ }^{16}$ Here, in this final section, God Himself makes a beautiful and moving address to the soul at peace (al-nafs al-muța'inna): ${ }^{27}$ You, soul at peace: ${ }^{28}$ return to your Lord well pleased and well pleasing; ${ }^{29}$ go in among My servants; ${ }^{30}$ and into My Garden.' To understand the soul at peace (muțma'inna) here, we need to recall Q. 13:28-29, which gives us a further description of ${ }^{28}$ those who have faith and whose hearts find peace (tatma'innu qulübuhum) in the remembrance of God-truly it is in the remembrance of God that hearts find peace $-{ }^{29}$ those who believe and do righteous deeds: joy awaits these, and their final homecoming will be excellent.' Both these descriptions follow statements that God sometimes gives in plenty and sometimes sparingly (Q. 89:1516, and Q. 13:26 respectively). This description of how humans can find peace in this world, and how it will be given to them in the next, contrasts sharply with the preceding condemnation of the all-consuming greed of oppressors in this world and their anguish on the Day of Judgement when they fully realise they have not behaved as they should, and the horror they will feel when Hell comes before them in full view.

On a grammatical level, note here the fașl ('disjunction') between sections three 
and four: this final section is not joined grammatically to the previous one with any conjunction in Arabic. This dramatic break emphasises the huge contrast between the two thematic units but highlights the semantic connection of contrast. The text is undoubtedly coherent in that both sections are devoted to describing the destiny of both groups; the oppressors and the souls at peace. ${ }^{17}$ The stylistic use of contrast between the destinies of the good and bad is a common feature of Qur'anic style, which is used on many occasions. It is announced, in many cases, in short scenes that occur after textual demonstration of the dismal end that awaits the sinners and the unbelievers except for those who believe and do good deeds (illä'lladhina amanū wa'amilū'l-șālihāt), see for instance Q. 84:25, Q. 95:6, and Q. 103:3, but sometimes also occurs without illa, by means of simple contrast as we find in $\mathrm{Q}$. 85:11, Q. 88:8, and Q. 89:27.

In Bell's discussion of this sura, he, as mentioned in the introduction to this piece, stated that after verse 14 'the rest of the sura is confused in rhyme and the sense is also uneven', ${ }^{18}$ without giving further explanation or evidence. However his view is mistaken. The fact is that rhyme is important in the Qur'an but it is always set aside when the sense requires otherwise. This can be seen here in verses 23 and 24: the first verse ends with $d h i k r \bar{a}$, but the second ends with hayāti, departing from the rhyme to observe the sense. As has been argued above, the 'sense' of this sura is even and, thematically speaking, the material progresses naturally and logically. Over and above this, the repetition of certain words and concepts fuse the various sections of the sura: rabbuka (your Lord) occurs in vv. 6, 14, and 22, followed by rabbika in v. 28; sawt al- 'adhāb (scourge of punishment) in Section 2 is echoed in 'adhābahu (as He punishes) and wathāqahu (as He binds) in vv. 25-6. There is obvious use of contrast between, for example, oppressive displeasure in v. 16 and anguish in v. 24 on the one hand and the pleasure (rādiya) of the soul at peace in v. 27; between 'he has humiliated me' (ahānani) in v. 16 and mardiyya (well pleasing) in v. 28; and between the themes of entering hell and torture in section 3 , and and enter[ing] my Paradise in section four. These contrasts fuse the material in the sura together and lend it thematic and lexical coherence.

With regard to Bell's comments on the later addition of material to the sura, he considers that ' $v v \cdot 18-21$ ' (in his numbering system, vv. 17-20 in the Egyptian edition numbering) 'seem very much later'. ${ }^{19}$ However, in my opinion, on the basis of a thematic reading of the sura and support from other parts of the Qur'an, it is clear this passage is a direct retort to the assertion of the unnamed character in verses 15-16 that, 'My Lord has honoured me ... He has scorned me'. The retort is, No, but you yourself do not honour the orphan! It would seem unlikely that these verses could have been later additions, as they appear to be integral to the discussion taking place in the text.

Bell considers verses $15-16$ to be an original part of the sura. ${ }^{20}$ However Jones 
reports that 'Neuwirth made a plausible reconstruction of a version prior to the present [sura] by excluding these verses'. ${ }^{21}$ In my opinion, however, the verses on the unnamed man being pleased and then displeased could not possibly have been separated at any time from their oppression of the orphans: the nature of this wavering man is the source of his bad behaviour.

Bell further considers that verses 23-25, when Hell is that Day brought near-on that Day man will take heed, but what good will that be to him then? He will say, 'Would that I had proivded for this life to come. On that Day no one will punish as He punishes, seem 'very much later',' 22 and this was followed by Neuwirth, according to Jones, ${ }^{23}$ who considered it 'plausible'. However these verses could not have been added later. In the internal logic of the sura, it is Hell's presence above all, that shakes the unnamed man into remembering. We should also read in this connection, Paradise was brought near and Hell exposed ... (Q. 26:96-97) and on that Day man will remember what he has done and Hell is exposed for all to see $(\mathrm{Q}$. 79:35-36).

Bell conjectures that 'probably the passage consisted originally of vv.14-17 (i.e. "when his Lord honours him ... my Lord has scorned me") followed by a judgement scene'. In my reading of the sura, this could not possibly have been the case. The terrible punishment mentioned in these verses was not simply for man's saying, 'My Lord has honoured me ... my Lord has scorned me', but for the cruel oppression of orphans, and the mistreatment of the poor and needy that follow these verses.

\section{Value of Bell's analysis?}

In the above discussion we dealt with the structure of the sura and explored the meanings of expressions such as layālin 'ashr, shaf' and watr, awtād, turāth, and nafs al-mutma'inna. We have also discussed Bell's analysis of Sūrat al-Fajr and should now consider the value of this analysis. Two features can be readily observed in this. First, when Bell makes statements such as, 'A number of verses were introduced into the sura at a later date which cannot be determined', he does not give any evidence or explanation to back up his assertions. Indeed, I have shown evidence that his claims in this respect cannot be correct. When there is evidence that a part of a sura was 'added' later, as for example in Sura 96, where we know from history that the first two lines were revealed in the Cave of Hira as the first verses of the Qur'an and the rest came later, the relevant question would then be how the new material fits and contributes to the overall effect of the sura. ${ }^{24}$ Secondly, Bell overuses such words as 'seems', 'probably', 'possibly' 'looks like' 'not intelligible', and 'cannot be determined'. ${ }^{25}$ This hesitant speculation is not confined to his treatment of Sürat al-Fajr, but is widespread. In one page, I counted at least 18 such expressions. ${ }^{26}$ Although it is a mark of good scholarship not to be dogmatic, it is questionable to be this uncertain: people read translations in order 
to understand and appreciate a text, not to be faced with such a widespread exercise in speculation. Clearly Bell was addressing his academic peers, not the general reader, but even to academics the value is questionable. Besides, after all his speculation, Bell still produced the text of Sūrat al-Fajr in the conventional order of material. Such analysis therefore did not lead anywhere, and does not help anyone understand or appreciate the text. It puzzles readers when the author himself feels 'it is impossible to say'. It overshadows the dawn.

As I hope is clear from the preceding exploration of this sura, its structure is, in fact, clear, logical and smooth. It begins with assurance to the Prophet by oath, then gives evidence from history that God is on the watch for oppressors both in the past and in Mecca, where they oppress orphans. It goes on to describe the punishment, both worldly and eschatological, that awaits oppressors, and contrast this with the honour and great rewards that await the soul at peace. So it is not impossible to see how the verses were conjoined together: Sürat al-Fajr warns the oppressor that God is on the watch, and reassures the Prophet and the faithful, the first word being, 'By the dawn', the last 'My Paradise'.

\section{NOTES}

1 Bell, The Qur'an Translated, vol. 2, p. 654.

2 Edited by C.E. Bosworth and M.E.J. Richardson.

3 Bell, like all Western scholars up to his time followed the Flugel numbering system. Since Arberry's translation, Western scholars have accepted the numbering system given in what they call the Egyptian mușhaf system of numbering, which I follow in my translation. Hence the differences in comparing translations, For instance v. 2 in my translation is part of v. 1 in Bell's. Moreover v. 25 in my translation is Bell's 25b.

4 Badawi and Abdel Haleem, Arabic-English Dictionary, p. 695.

5 Alan Jones considers it to be 'a 'cryptic oath ... typical of kahin-style material' without offering any further explanation. Jones, The Qur'an, p. 570.

6 al-Rāzī, al-Tafsìr al-Kabīr , Volume 16, part 31, p. 162.

7 al-Rāzī, al-Tafsīr al-Kabīr, Volume 16, part 31, p. $163 \mathrm{ff}$.

8 Bell, ibid. Jones, ibid.

9 See 'Divine Oaths' in Abdel Haleem, Exploring the Qur'an, pp. 177-211.

10 al-Hāshimī, Jawāhir al-balāgha, pp.198-20 footnotes.

11 Awtād is often translated into English as 'peg', although it can also mean 'wall', while awtād al-ard means mountains (Q. 79:7) and it is more likely that it here means columns/obelisks, or even pyramids, as this interpretation is more in harmony with the preceding images of the columns of Iram and pillars carved into the rock of the Thamūd.

12 This is similar to Q. 58:4, which covers preceding and following wrongs.

13 al-Rāzī, al-Tafsìr al-Kabīr, Volume 16, part 31, p. 172.

14 Compare Q. 41:49-50 and Q. 17:83-4.

15 al-Rāzī, al-Tafsīr al-Kabīr, Volume 16, part 31, p.171, and al-Bayḍāwī, Tafsir, vol. 2, p. 595. 
16 Compare this with Q. 55:39-41, ${ }^{39}$ On that Day neither mankind nor jinn will be asked about their sins. ${ }^{40}$ Which, then, of your Lord's blessings do you both deny? ${ }^{41}$ The guilty will be known by their mark and will be seized by their foreheads and their feet.

17 A. Al-Hashimi, Jawahir al-balāgha ...

18 The Qur'an Translated, vol. 2, p. 654.

19 The Qur'an Translated, vol. 2, p. 654.

20 The Qur'an Translated, vol. 2, p. 654.

21 Jones, The Qur'ān, p. 576.

22 The Qur'an Translated, vol. 2, p. 654.

23 Jones, The Qur'ān, p. 576.

24 A similar case is verse 20 of Sura 73.

25 Bell, The Qur'an Translated, vol. 2, p. 654.

26 Bell, The Qur'an Translated, vol. 1, pp. 248-249. 